\title{
PAMIĘCI NIEUKOJONE. WOKÓŁ UPAMIĘTNIANIA OFIAR W SERBII I CHORWACJI (JASENOVAC, BLEIBURG I BELGRADZKIE SAJMIŠTE)
}

\author{
SABINA GIERGIEL ${ }^{1}$ \\ (Uniwersytet Opolski)
}

\begin{abstract}
Słowa kluczowe: przeszłość, wojna, praktyki komemoratywne, miejsce pamięci Key words: past, war, commemorative practices, memorial site
\end{abstract}

\begin{abstract}
Abstrakt: Sabina Giergiel, PAMIĘCI NIEUKOJONE. WOKÓE UPAMIĘTNIANIA OFIAR W SERBII I CHORWACJI (JASENOVAC, BLEIBURG, BELGRADZKIE SAJMIŠTE). „PORÓWNANIA" 19, 2016. T. XIX. S. 130-149. ISSN 1733-165X. Tekst koncentruje się na przemianach tożsamości narodowych w dwóch krajach postjugosłowiańskich (Serbii i Chorwacji). (Re)konstrukcje przeszłości mające tam miejsce od lat dziewięćdziesiątych XX wieku zakładały przede wszystkim zanegowanie dziedzictwa wspólnego opartego na zmitologizowanej walce partyzanckiej, a następnie wybór z przeszłości tych wydarzeń, o których pamięć należy kultywować. Walka przeciwstawnych pamięci (serbskiej i chorwackiej) oraz polaryzacja społeczeństwa chorwackiego pokazana zostaje na przykładzie praktyk komemoratywnych związanych z miejscami zagłady (Jasenovac i Bleiburg) z okresu drugiej wojny światowej. W tekście przywołano również miejsce kojarzone z Holokaustem, które mogłoby stać się symbolem uniwersalnej, "pogodzonej” pamięci.
\end{abstract}

\begin{abstract}
Sabina Giergiel, THE INCONSOLABLE MEMORIES. ON COMMEMORATING PRACTICES IN SERBIA AND CROATIA (JASENOVAC, BLEIBURG, BELGRADE'S SAJMIŠTE). "PORÓWNANIA" 19, 2016. Vol. XIX. P. 130-149. ISSN 1733-165X. The paper focuses on the national identity transformations in the two post-Yugoslavian states, i.e. Serbia and Croatia. (Re) constructions of the past that have been taking place there since the 1990s mainly assume rejecting the common legacy based on the mythological guerilla fight, and then choosing those past events about which memories ought to be retained. The struggle of the adversative pasts (Serbian and Croatian), as well as the polarization of the Croatian society are demonstrated on the example of the commemorative practices connected to the memorial sites from the World War II (Jasenovac and Bleiburg). The paper also alludes to the site associated with Holocaust which might become the symbol of the universal, "reconciled" memory.
\end{abstract}

1 E-mail: sgiergiel@uni.opole.pl 
Określanie wydarzeń, które dla danej kultury i dla członków narodu stanowić będą ważne punkty odniesienia $\mathrm{w}$ procesie samoidentyfikacji, nigdy nie odbywa się w znaczeniowej próżni. Zwykle już sam zestaw elementów składowych narodowych imaginariów wskazuje na to, jakie treści w danej społeczności uznane zostały za kanoniczne, a jakie zepchnięte na margines bądź też całkowicie wymazane. Decyzję o tym, co należy włączyć do świadomości obywateli, a co z niej usunąć, najczęściej podejmują przedstawiciele grup dzierżących władzę. Potrzeba wybrania podstawowych punktów odniesienia dla członków społeczności jest zadaniem szczególnie istotnym w sytuacji, gdy państwo (lub pewna zbiorowość) musi potwierdzić rację bytu poprzez zanegowanie niedawnej przeszłości. Jak trafnie zauważa Paul Connerton, „wszystkie początki zawierają element przypomnienia. Jest tak zwłaszcza wtedy, gdy grupa społeczna dokonuje wspólnego wysiłku, by rozpocząć wszystko na nowo" (Connerton 39). Przeszłość odgrywa zatem niezwykle ważną rolę w konsolidacji obywateli wokół dyskursów narodowych, zwłaszcza w nowopowstałych państwach.

$\mathrm{Z}$ taką sytuacją mieliśmy do czynienia $\mathrm{w}$ krajach postjugosłowiańskich, które $\mathrm{w}$ latach osiemdziesiątych, a zwłaszcza dziewięćdziesiątych ubiegłego wieku rozpoczęły proces ponownego konstruowania własnych tożsamości. Przebiegało to $\mathrm{w}$ sposób niezwykle gwałtowny, a sam proces połączony był z jawnym negowaniem wspólnej przeszłości i wytwarzaniem - opartych na kryterium narodowym - nowych kanonów kulturowych.

W centrum zainteresowania w niniejszym tekście znalazły się dwa kraje, będące dziś najważniejszymi „,spadkobiercami” Jugosławii, a więc Serbia i Chorwacja. Oba te państwa od lat osiemdziesiątych powoli rekonstruują własną tożsamość, szukając $\mathrm{w}$ przeszłości fundamentów swej odmienności. W latach dziewięćdziesiątych, kiedy poprzedzona bratobójczą walką odrębność państwowa stała się faktem, problem ten stał się palący. Jednak ze względu na fakt wieloletniego pozostawania w jugosłowiańskiej wspólnocie determinującej wspólną historię poszukiwanie odrębności - $w$ istocie legitymizującej niezależność - niejednokrotnie polegające na jej "wytwarzaniu" ${ }^{2}$, nabrało rozpędu.

Państwowe uroczystości, będące rodzajem rytuału utrwalającego wspólnotę, są doskonałym przykładem na to, jak oba interesujące nas kraje, konstruując tożsamość wspólnoty w oparciu o wydarzenia historyczne, wchodzą ze sobą w konflikt ${ }^{3}$. Ma on w tym wypadku charakter nie tyle militarny, ile "memoracyjny" - by posłużyć się tutaj stworzonym ad hoc neologizmem. Po raz kolejny na terenach postjugosłowiańskich rozgrywa się wojna, tym razem będąca rodzajem wojny pamięci czy też wojny

2 Zagadnienia (re)konstrukcji tradycji narodowej w państwach postjugosłowiańskich były w ostatnich latach często podejmowane przez polskich slawistów. Ja w tym miejscu ograniczę się jedynie do przywołania monografii, które wyczerpująco i w ciekawy sposób opisują te procesy. Zob. Dyras; Jawoszek; również Miodyński.

3 Oficjalne praktyki upamiętniania są według Jamesa Younga „ucieleśnieniem ducha i pamięci narodu". (Young 271). 
o pamięć. Prześledzenie kontrowersji wokół miejsc pamięci oraz obchodów upamiętniających dwa tragiczne (związane z miejscami zagłady) wydarzenia z XX-wiecznej historii obu narodów (serbskiego i chorwackiego) pokazuje nie tylko szlak, na jaki ukierunkowana zostaje pamięć historyczna tych zbiorowości, ale i wartości będące w centrum uwagi władz państwowych. Co więcej, praktyki komemoratywne odbywające się $\mathrm{w}$ dwóch najważniejszych lokalizacjach związanych $\mathrm{z}$ ofiarami drugiej wojny światowej (Jasenovac i Bleiburg) zarówno obrazują żywy w obu krajach spór dotyczący przeszłości, jak i odzwierciedlają rozłam istniejący w samej Chorwacji ${ }^{4}$.

$\mathrm{Na}$ wstępie warto również podkreślić, że kwestie, o których zamierzam tu pisać, są stosunkowo dobrze znane przedstawicielom obu narodów oraz zagranicznym slawistom. $W$ ostatnim czasie $w$ serbskich i chorwackich tomach zbiorowych ukazało się kilka tekstów poświęconych temu zagadnieniu, opublikowane zostały również monografie związane z problematyką szeroko pojętej polityki pamię$\mathrm{ci}^{5}$. Zdarza się jednak, że artykuły dotyczące tego tematu (teksty o charakterze naukowym, a więc mające w założeniu być neutralne, obiektywne) są stronnicze, co pośrednio dowodzi, jak bardzo kwestie związane z dramatycznymi momentami z przeszłości są wciąż żywe $w$ tych społeczeństwach. Na marginesie pojawia się tu pytanie, czy w kontekście tak trudnego zagadnienia jak upamiętnianie ofiar z jednej strony i wina - z drugiej, bezstronność jest w ogóle możliwa. Pamięć wspólnoty jest przecież zawsze, w mniejszym lub większym stopniu, ,zarządzana”, ,"zagospodarowywana”, ,kształtowana”, "używana”, zaś działania mające na celu upamiętnienie (a temu służą przecież wszelkie praktyki komemoratywne) niezwykle łatwo przekształcić się mogą w manipulację, ideologizację czy polityzację (Zertal). Nie decydując się na rozstrzygnięcie tego problemu, dodam jedynie, że bliska jest mi teza, iż piszący zawsze mówi z jedynego w swoim rodzaju miejsca, że to, co mówi, zawsze jest uwarunkowane jego sympatiami/antypatiami, gustem czy wyznawanym kodeksem wartości.

4 Polaryzację społeczeństwa chorwackiego wokół upamiętniania Jasenovaca i Blaiburga niezwykle wnikliwie analizują Maciej Falski i Tomasz Rawski w artykule Jasenovac, Bleiburg, Vukovar: miejsca pamięci a dyskurs publiczny (Falski, Rawski 193-214) oraz Vjeran Pavlaković (Pavlaković 43-81). Tezy zaprezentowane $\mathrm{w}$ artykule polskich badaczy $\mathrm{w}$ wielu miejscach pokrywają się z moimi, choć niniejszy tekst ma nieco ogólniejszy charakter.

5 Są to m.in. artykuły zebrane w kolejnych tomach wydawanych w Zagrzebiu pod wspólnym tytułem: Kultura sjećanja. Povijesni lomovi i svladavanje prošlosti. Poświęcone są one granicznym datom z dwudziestowiecznej historii. Do tej pory ukazały się tomy poświęcone latom: 1918 (red. O. Milosavljević, T. Cipek, Zagreb 2007), 1941 (red. S. Bosto, T. Cipek, O. Milosavljević, Zagreb 2008) oraz 1991 (red. T. Cipek, Zagreb 2011). Zob. również tomy pod redakcją Gordany Đerić: Intima javnosti. Okviri predstavljanja, narativni obrasci, strategie i stereotipi konstruisanja Drugosti u upečatljivim događajima tokom razgradnje Jugoslavije: štampa, TV, film (Beograd 2008); Pamćenje i nostalgija. Neki prostori, oblici, lica i naličja (Beograd 2009) oraz książki Todora Kuljicia: Prevladanje prošlosti. Uzroci i pravci promene slike istorije krajem XX veka (Beograd 2002) i Kultura sećanja. Teorijska objašnjenja upotrebe prošlosti (Beograd 2006), jak również tom Danila Trbojevicia, Sećanje na zlo. Politika komemoracije žrtava nacističkih ustaških logora (Beograd 2014). 
Biorąc pod uwagę fakt, iż kontrowersje wokół upamiętniania obozu w Jasenovacu, masakry w Bleiburgu, (nie)istnienia w przestrzeni znaczącej miasta miejsca, w którym niegdyś mieścił się belgradzki obóz Sajmište (bo te właśnie naznaczone śmiercią przestrzenie sytuują się w centrum moich zainteresowań), zostały już dość dobrze rozpoznane na gruncie południowosłowiańskim, należy tutaj podkreślić, że moje zadanie ogranicza się $\mathrm{w}$ dużej mierze do sprawozdania $\mathrm{z}$ dyskusji, przywołania faktów oraz opisu „walki” dwu pamięci. Wybór lokacji, które wymagają upamiętnienia (tzw. miejsc pamięci) (Nora 4-12; Szpociński 11-20), i sposoby ich kontekstualizacji doskonale pokazują, w jaki sposób - za ich pomocą - w obu krajach dokonywane są akty legitymizacji władzy, procesy definiowania wroga ( $w$ interesującym nas przypadku jest to demonizacja - paradoksalnie jeszcze niedawno bliskiego - Innego ${ }^{6}$ i konstruowanie fundamentów nowego państwa (z często wykorzystywanym mitem ofiary ${ }^{7}$ ). Te procesy są zbieżne z przemianami dyskursu historycznego, które - upraszczając i rezygnując z oryginalności - można sprowadzić do odwrotu od tzw. wielkich narracji na rzecz opowieści lokalnych. W wypadku byłych republik jugosłowiańskich związane są one również ze specyfiką społeczno-polityczną tego regionu w ostatnich dziesięcioleciach, o czym pośrednio była już tutaj mowa.

Końcówka lat osiemdziesiątych, a zwłaszcza lata dziewięćdziesiąte to okres, w którym konstruują swoją tożsamość, a następnie powstają nowe państwa. Jest to również czas, kiedy otwarcie zaczyna się mówić o tematach do tej pory spychanych poza obowiązujący dyskurs. Warto mieć na względzie fakt, że z perspektywy końca XX wieku powojenna historia Jugosławii wygląda inaczej niż w dziesięcioleciach bezpośrednio po niej następujących. Ogromne znaczenie ma tu oczywiście fakt, że państwa powstałe na jej gruzach mają za sobą doświadczenie bratobójczej wojny, a więc społeczeństwa te dotknęło tragiczne załamanie się historii, dramatyczny przełom, a nawet pewien regres. Trafne jest w tym kontekście spostrzeżenie, że wojna jest momentem, który powoduje zaburzenia w dotychczasowym oglądzie przeszłości, wręcz prowadzi do redefiniowania znaczeń związanych z pewnymi wydarzeniami historycznymi ${ }^{8}$. Wojna zatem zmienia pamięć o czasie, który poprzedzał wybuch konfliktu, co (zapewne w pierwszej kolejności) związane jest z próbą spojrzenia na przeszłość w kontekście zarówno przyczyn, jak i bezpośrednich skutków ${ }^{9}$. Konstruowanie nowych znaczeń $\mathrm{w}$ warunkach powojennych powiązane

6 Mam tu na myśli symboliczne i realne odcinanie się od konstytutywnej dla powojennej Jugosławii idei wyrażającej się w haśle braterstwa i jedności.

7 Wpisaną w kulturę serbską koncepcję istnienia narodu jako ofiary, mającą swe źródło w „zwycięskiej klęsce" na Kosowym Polu w 1389 roku, dokładnie analizuje Dorota Gil (zob. Gil, również Dąbrowska-Partyka).

8 Piotr Sztompka nazywa to "traumą wielkiej zmiany” (Sztompka).

9 Zwraca na to uwagę Tihomir Cipek we wstępie do tomu, w którym zebrano teksty z konferencji poświęconej pamięci o 1991 roku (Cipek 2011: 7-10). 
jest ponadto z orientacją ideową osób dzierżących władzę, a zatem każdy przewrót wywoływać będzie nieco inne spojrzenie na historię i przeszłość wspólnoty.

Niezwykle ciekawe, a zarazem symptomatyczne dla procesów związanych z tworzeniem się kolejnych organizmów państwowych na terenach byłej Jugosławii jest prześledzenie, jak zmieniały się na przestrzeni lat ramy oficjalnej pamięci oraz implikacje związane z tymi przemianami. Aby jednak móc wskazać przekształcenia, które w ostatnich dziesięcioleciach dotyczą pamięci o przeszłości na tych terenach, w pierwszej kolejności należy odnieść się do dominującej narracji jugosłowiańskiego państwa. To wobec niej konstruowane są (najczęściej opozycyjnie) nowe praktyki upamiętniania. Okres drugiej połowy XX wieku w kulturze, dyskursie oficjalnym i potocznej świadomości został tam bowiem zdominowany przez etos partyzancki, który w swej istocie był dla federacyjnej Jugosławii mitem założycielskim, mitem z jasno określonym podziałem na dobro i $z^{\prime}{ }^{10}$. Po drugiej wojnie światowej powszechne stało się (u podstaw słuszne) przekonanie, że to partyzantka komunistyczna powstrzymała wojska faszystowskie. Przekłamanie wiązało się jednak z wtłaczaniem obywatelom wiary, że jedynie partyzanci zakończyli wojnę jako siła moralnie czysta (w odróżnieniu od pozostałych grup biorących udział $\mathrm{w}$ walkach, nieprzystających do partyzantów) ${ }^{11}$. W wyniku takiego uproszczenia i monopolizacji pamięci o doświadczeniach wojennych niejako automatycznie w kręgu faszystów znaleźli się wszyscy przeciwnicy komunistów (zostali oni uznani za sprzymierzeńców okupanta). Jak każda opowieść założycielska, również i ta miała być jednoznaczna oraz nieskomplikowana, a to zakładało pominięcie tych fragmentów narracji wojennej, które kwestionowałyby ów wyrazisty aksjologicznie podział. W oficjalnej historii ruchu nie znalazły się zatem wydarzenia podważające czystość intencji partyzanckich bohaterów bądź też takie, które bezpośrednio odnosiłyby się do okrucieństw dokonywanych pod komunistycznym sztandarem. Joanna Rapacka zauważa, że autentyczne doświadczenia wojenne w socjalistycznej Jugosławii zostały zepchnięte $w$ krąg tradycji nieoficjalnej i wyjęte spod regulującego działania umysłu krytycznego (Rapacka 25-26). Nieprzepracowanie traumy $z$ lat drugiej wojny światowej oraz tabuizowanie niewygodnych dla władzy wydarzeń sprawiły, że symboliczna rana z czasów wojny nigdy nie miała szansy, by choć częściowo się zabliźnić.

Jednocześnie fakt istnienia wspólnego wroga i walka z nim (faszyzm) stały się doskonałym elementem integrującym $w$ ramach federacyjnego (a więc wcale nie jednolitego) państwa. Intensywna działalność państwowej propagandy wyrugowała ze społecznej pamięci skomplikowane i bolesne doświadczenia niedawnej wojny

10 Todor Kuljić takie jasne rozłożenie akcentów aksjologicznych uważa za jeden z wyznaczników „etnocentrycznych kultur pamięci" (Kuljić 2006: 287-289).

11 Należy podkreślić, że serbska literatura dość wcześnie zrywa z takim schematycznym widzeniem świata, od lat sześćdziesiątych (a nawet pięćdziesiątych) pojawiają się bowiem utwory kwestionujące mit partyzancki. 
(Rapacka 25). Walka z faszyzmem, jakiej w czasie drugiej wojny światowej i bezpośrednio po niej podjęła się komunistyczna partyzantka oraz jej oficjalni kontynuatorzy, tj. Komunistyczna Partia Jugosławii, dała zaś możliwość rozprawienia się z tzw. wrogami wewnętrznymi. $W$ ich szeregach znaleźli się zarówno przedstawiciele przedwojennej klasy średniej, kojarzonej ze zwolennikami monarchii, jak i realni przeciwnicy polityczni ${ }^{12}$. Już w 1944 roku oficjalnym dekretem uznano za dopuszczalne i sprawiedliwe odbieranie majątku osobom podejrzanym o współpracę z okupantem. Na tej podstawie z Banatu wysiedleni zostali Niemcy, a ich majątki przypadły tzw. „nowym kolonistom”"13. Tożsamość powojennej Jugosławii opierała się na kryteriach wspólnotowych (fundamentem integracji była walka z faszyzmem). Pod koniec XX wieku natomiast obserwować można na terenach byłej Jugosławii proces odwrotny, polegający na powrocie do wizji narodowych, wcześniej dość umiejętnie tłumionych ${ }^{14}$. W ten sposób demonizacja socjalizmu $\mathrm{w}$ jakimś sensie sprzęgła się z akceptacją nacjonalizmów. Wraz z rozpadem Jugosławii można obserwować proces ponownego wyznaczania wrogów. Jak pisze Maria Dąbrowska-Partyka:

w historycznej pamięci Bałkanu dominuje postać OBCEGO, NIEPRZYJACIELA, który nieustannie czyha na zgubę MOJEJ wiary, MOJEJ przestrzeni, MOJEJ wspólnoty. Obrona i atak, nieufność i poczucie zagrożenia, destrukcyjna ksenofobia to wzory, które historia tego miejsca zaszczepiła mieszkańcom Bałkanu (Dąbrowska-Partyka 102) ${ }^{15}$.

Od końca lat osiemdziesiątych można obserwować ponowne nasilenie procesów polegających na reinterpretowaniu historii i redefiniowaniu wroga. Aby jednak

12 Represje dotknęły zarówno politycznych oponentów, jak i przedstawicieli serbskiego mieszczaństwa (a więc potencjalne elity, klasę średnią). Pamięć o tych wydarzeniach rejestruje serbska literatura. Przemiany powojennego społeczeństwa serbskiego są bowiem jednym z tematów prozy Borislava Pekicia w takich utworach jak: Godine koje su pojeli skakavci, Graditelji, Hodočašće Arsenija Njegovana (w polskim przekładzie: Pielgrzymka Arsenijego Njegovana) oraz Slobodana Selenicia w książkach: Memoari Pere Bogalja (polski przekład: Pamiętnik Piotra Kaleki), Prijateljisa Kosančićevog venca (polski przekład: Ci dwaj mężczyźni).

13 Niewielka część Niemców z Wojwodiny wycofała się z Serbii razem z wojskiem. Ci, którzy zostali, trafili do obozów, część z nich została wywieziona do Związku Radzieckiego, pozostali zaś zostali wysiedleni w 1950 roku.

14 Do najbardziej znanych wybuchów niezadowolenia ze wspólnotowej polityki czasów Jugosławii należą wydarzenia z 1970 roku określane mianem maspoku lub chorwackiej wiosny. Wówczas przedstawiciele Komunistycznej Partii Chorwacji wyrazili żądania większej autonomii w ramach SFRJ. Warto dodać, że kultura popularna wciąż odwołuje się do partyzanckiej mitologii, gloryfikując czasy wspólnoty. Ponadto niezwykle liczna jest grupa osób, dla których kultura popularna lat siedemdziesiątych i osiemdziesiątych jest wciąż ważnym symbolem braterstwa i równości oraz (co może bardziej symptomatyczne) dawnych, szczęśliwych czasów. Tym zagadnieniom poświęcona jest książka Vjekoslava Pericy i Mitiji Velikonji (Perica, Velikonja).

$15 \mathrm{Na}$ budowanie narodowego modelu kultury w Serbii na fundamencie bycia „w opozycji do” czy „w defensywie wobec" zwraca również uwagę Gil. Zob. Średniowieczne piśmiennictwo serbskie jako dokument stanu świadomości narodowej oraz inne teksty zebrane w tomie Prawostawie. Historia. Naród (Gil). 
tego dokonać, na początku należało w odmętach zapomnianej lub usuniętej na margines historii odnaleźć wydarzenia, mogące stać się kamieniami milowymi nowej autonarracji ${ }^{16}$.

Podstawą konsolidacyjną staje się zatem propagowane i wtłaczane w świadomość mieszkańców przekonanie o wiecznym zagrożeniu czyhającym na przedstawicieli własnej grupy. Jednocześnie ma miejsce często bezrefleksyjne odcinanie się od okresu wspólnotowego, połączone z jednoznaczną krytyką jugosłowiańskiego socjalizmu. Co ciekawe, jawny antykomunizm i antyjugoslawizm, których wyraźne symptomy można obserwować $\mathrm{w}$ dyskursie publicznym niezależnych państw, będących spadkobiercami federacji, w Chorwacji (w której te procesy w latach dziewięćdziesiątych wydawały się szczególnie nasilone) nie przekłada się na założenia najważniejszych aktów państwowych. Wbrew temu, co mogłoby się wydawać jak pisze Maciej Falski, przywołując zapis konstytucji z 2001 roku - „Chorwacja socjalistyczna wpisuje się $\mathrm{w}$ oficjalne ramy pamięci jako gwarantka ciągłości bytu państwowego Chorwacji" (Falski 41). Biorąc to pod uwagę, możemy pokusić się o pewne uogólnienie i uznać, że państwa powstałe po rozpadzie Jugosławii charakteryzuje rodzaj schizofrenii związanej ze skazanymi na niepowodzenie próbami skonstruowania spójnej i logicznej wizji dziejów, w której znalazłoby się miejsce np. na podkreślenie trwałości istnienia samodzielnych bytów państwowych i o cięcie się od okresu istnienia $w$ ramach federacji. Jedną $\mathrm{z}$ cech powszechnie akceptowanej wizji dziejów jest jej bezkonfliktowość, a o taką jej formę w przypadku państw postjugosłowiańskich - jak nam się wydaje - wciąż trudno, gdyż każda próba zakwestionowania wagi zwycięstwa partyzantki w drugiej wojnie światowej oraz następujących po niej latach komunizmu pociąga za sobą rewizję spojrzenia na faszyzm. Według Todora Kuljicia taki charakter mają konstrukcje myślowe, w których na pierwszy plan wysuwa się teza oparta na przekonaniu, że Jugosławia mogła w 1941 roku zachować neutralność, a zatem niepotrzebnie zaangażowała się $\mathrm{w}$ walkę z niemieckim okupantem. Wedle tej opinii serbski antyfaszyzm był jedynie irracjonalnym i szkodliwym buntem. Kuljić za swoistą relatywizację antyfaszyzmu uznaje również negowanie półwiecza wspólnego istnienia w ramach Jugosławii i przekonanie, że dla historii Serbii rok 2000 jest przełomowy, wtedy to bowiem ma

16 Wydaje się jednak, że niejednokrotnie popularyzowane przez oficjeli centralne punkty pamięci zbiorowej rozmijają się z identyfikacją jednostek. A zatem społeczeństwo potrafi, wbrew nowym czy zmodyfikowanym ramom pamięci narzucanym przez dzierżących władzę, walczyć o indywidualną pamięć i przeciwstawić się oficjalnemu dyskursowi. Za przejaw buntu wobec władzy manipulującej pamięcią, a zarazem gwałtownie wkraczającej w znaczącą tkankę miasta, uznać można chociażby opór społeczności Zagrzebia wobec prób przemianowania miejskiego rynku. Wg powojennej nomenklatury plac ten upamiętniał ofiary antyfaszystowskiej walki (Trg žrtava fašizma). Nowe władze Zagrzebia próbowały zmienić jego nazwę, przemianowując rynek na Trg hrvatskih velikana, tj. Plac chorwackich bohaterów, jednak wobec sprzeciwu mieszkańców Zagrzebia wycofano się $\mathrm{z}$ tego pomysłu. Zagadnieniu konkretyzowania się historii w zagrzebskiej toponimii poświęcona została część artykułów w książce Dunji Rihtman-Auguštin Ulice moga grada (Rihtman-Auguštin). 
miejsce powrót do przerwanego w 1945 roku kontinuum (Kuljić 2002: 419) ${ }^{17}$. Falski z kolei zauważa, że odrzucenie przez Chorwację wspólnego dziedzictwa państwowego w sposób automatyczny pociągałoby za sobą konieczność oparcia suwerenności na tworze wcześniejszym, a więc na faszystowskim quasi-państewku NDH (Nezavisna Država Hrvatska - Niezależne Panstwo Chorwackie), co z oczywistych względów wydaje się problematyczne (Falski 40).

Jak to już zostało zasygnalizowane, w czasie konfliktu zbrojnego z lat dziewięćdziesiątych ponownie wróciły upiory drugiej wojny światowej. W jednej z obowiązujących po obu walczących stronach narracji wyraźnie podkreślano, że aktualny konflikt ma swoje bezpośrednie korzenie $w$ wydarzeniach $\mathrm{z}$ lat czterdziestych XX wieku. W tym kontekście można zatem mówić o nieprzepracowanych traumach historycznych. Powiększający się dystans dzielący współczesność od czasów drugiej wojny światowej nie sprawia, że pamięć o niej blednie. Wprost przeciwnie: to właśnie wydarzenia z wojny są puntem spornym pomiędzy różnymi, skonfliktowanymi ze sobą narracjami historycznymi: zarówno serbsko-chorwackimi, jak i tymi, które obecne są w obu krajach (szczególnie wyraźnie widać to w Chorwacji, o czym przekonująco piszą przywoływani już tutaj kilkarotnie badacze, Pavlaković oraz Falski i Rawski). Tragiczne wydarzenia wojenne na całe lata określiły stosunki z sąsiadami państw powstałych po rozpadzie Jugosławii oraz podzieliły społeczeństwo, polaryzując je wokół różnych (czasem wzajemnie sprzecznych) interpretacji wydarzeń z przeszłości.

$\mathrm{W}$ procesie ponownego tworzenia pożądanej wersji historii szczególnego znaczenia nabierają tragiczne wspomnienia, związane z miejscami masowych mordów i cierpień jednostek. Za ich pośrednictwem przeszłość, która jest po raz kolejny odtwarzana i przeżywana w swoistej repetycji, powraca niczym widmo. Dominick LaCapra, wyraźnie nawiązując do Freudowskiego rozróżnienia melancholii i żałoby, podkreśla, że ta druga zakłada właśnie pamięć, ale i jednoczesne dystansowanie się wobec przeszłości, umożliwiające powrót do życia, zwłaszcza społecznego i obywatelskiego, z uwzględnieniem odpowiedzialności, wymogów i norm związanych z szacunkiem dla innych (LaCapra 2015: 90, Freud 1991a: 295-308) ${ }^{18}$.

17 Rok 2000 oznacza odejście od polityki Slobodana Miloševicia i zmianę kursu Serbii. Szczególne znaczenie mają wydarzenia z 5 i 6 października 2000 roku, kiedy to w wyniku burzliwych demonstracji przeciw Miloševiciowi dochodzi do - poprzedzonej uznaniem przez dotychczasowego prezydenta porażki wyborczej - zmiany władzy.

18 Według Connertona to właśnie obrzędy komemoratywne mają funkcję aktualizowania przeszłości (Connerton). Zagadnienie niezabliźnionych ran i nieukojonej przeszłości podejmuje David Albahari w książce Mamidło, w takim właśnie pojmowaniu minionego widząc jedną z przyczyn wybuchu bratobójczej wojny na terenach Jugosławii. Dla ilustracji przywołamy tutaj niezwykle symptomatyczny cytat. Otóż na pytanie kanadyjskiego przyjaciela, dlaczego w jego kraju toczy się wojna, bohater (Serb o żydowskich korzeniach) odpowiada: „Chodzi o winę. [...] Są tacy [...], którzy twierdzą, że najważniejsze jest poznanie winnych czegoś, co rozegrało się w bliższej bądź dalszej przeszłości; nawet gdyby przy okazji stwarzano nowych winnych, nawet gdyby przy okazji unicestwiono wszelką możliwość życia tylko pamięcią o winie. I oczywiście [...] kiedy tacy ludzie zwrócili się do Żydów z żądaniem, by jako świadkowie wskazali winnych, wspólnota żydowska jedynie 
Poprzedzone wyborem wydarzeń upamiętnianie ofiar należy przeżyć szczególnie uroczyście, staje się ono w obu nowych państwach znakiem tego, na jakich fundamentach kraje te zamierzają oprzeć swą tożsamość. Również wybór ofiar, nad którymi należy się pochylić w wyjątkowy sposób, jest już w swej istocie symbolicznym komunikatem dotyczącym tego, co według dzierżących władzę jest dla danej wspólnoty wiążące i ważne. Albowiem, jak powszechnie wiadomo, oficjalne obrzędy komemoratywne, związane z konkretnymi wydarzeniami (najczęściej traumatycznymi), mają moc spajania grupy. To wokół nich koncentruje się kolektywna pamięć, na chwilę wymazuje się/ zastępuje pamięć jednostkowa. A zatem za ich sprawą dokonuje się instytucjonalnie zatwierdzony proces przebudowy bądź utwierdzania społecznej pamięci. W związku z tym, że jednym z fundamentów nowej tożsamości krajów powstałych po rozpadzie Jugosławii jest pamięć o własnych ofiarach połączona z odsuwaniem od siebie winy za cierpienia innych, ma w nich miejsce swoista walka pamięci, polegająca między innymi na wzajemnym licytowaniu się liczbami ofiar czy na próbach umniejszania bądź relatywizacji własnej odpowiedzialności za zbrodnię. W tym właśnie kontekście Kuljić pisze o obozie Jasenovac, którego istnienie w pewnych kręgach tłumaczy się jako zbrodnię chorwackich zdrajców, ludzi z marginesu, którzy pojawili się w szeregach ustaszy, czy o masakrze w Srebrenicy przez niektórych eufemistycznie nazywanej „przesadnym odwetem Serbów”, a nawet określanej mianem operacji „,oswobadzania miasta” (Kuljić 2002: 418; 2006: 295).

Ponadto badacz zwraca uwagę, że monumentalizacja własnych (tzn. narodowych) miejsc pamięci mobilizuje do odpowiedzi przedstawicieli narodu, z którego pochodzili winni. Na tej zasadzie niejednokrotnie Serbowie i Chorwaci przeciwstawiają sobie Jasenovac i Bleiburg, odpowiednio tłumacząc własne historyczne przewinienia (Kuljić 2006: 294-297). Oba kraje (Serbia i Chorwacja) zdają się wciąż ze sobą walczyć. Podkreślmy raz jeszcze: tym razem nie militarnie, ale raczej za pomocą pamięci, tworząc opozycyjne względem siebie, wyraziste kontrmartyrologie. Kultura pamięci, która u swych podstaw ma nieprzepracowane traumy historyczne, nie może być zjawiskiem trwałym. Wydaje się ponadto, że jest ona w sposób szczególny narażona na manipulację. Kuljić twierdzi wręcz, że społeczność żyjąca w takiej kulturze w sprzyjających okolicznościach jest skłonna po raz kolejny przyswoić sobie pozycję ofiary i uznać, że należy pomścić cierpienia członków własnej wspólnoty (Kuljić 2002: 409) ${ }^{19}$. Tutaj właśnie dochodzi do głosu jeden ze sposobów radzenia sobie ze zdarzeniami granicznymi, który LaCapra określa terminem roze-

wyciągnęła spisy imion oraz miejsc i odmówiła zabrania głosu. Z tych spisów widać było czarno na białym [...], że wszyscy biorący udział w poprzedniej wojnie, która w wizji tych, co domagali się wskazania winnych, miała być wojną prowadzoną teraz, tak jakby można było wrócić przeszłość, a więc, że wszyscy [...] z wyjątkiem partyzantów zabijali Żydów w tamtej wojnie, i dlatego wspólnota żydowska nie wierzy we wskazywanie winnych, tylko we wskazywanie ofiar" (Albahari 2008: 110). I w innym miejscu pisze: „Kto obcuje z historią, nie obcuje z życiem, jest martwy, nawet gdy żyje" (Albahari 2008: 94).

19 Za przeciwwagę wobec tego rodzaju postwy można uznać tzw. „pamięć pogodzoną" (Ricoeur). 
grania w działaniu (acting out) (LaCapra 2009, Freud 1991b: 266-272). W odróżnieniu od mechanizmu przepracowania (working through), który gwarantuje powrót do równowagi, $\mathrm{w}$ społeczeństwach serbskim i chorwackim $\mathrm{w}$ ostatnich dziesięcioleciach mieliśmy do czynienia z kompulsywnym powracaniem do dramatycznych wydarzeń, z cyklicznym ich odtwarzaniem, co prowadzi do uwznioślenia wydarzeń granicznych, ofiar, a nawet całego narodu.

W tym miejscu nasza uwaga skoncentruje się na praktykach komemoratywnych i na kontrowersjach związanych z dwoma - budzącymi najwięcej emocji w społeczeństwach serbskim i chorwackim - przestrzeniami naznaczonymi śmiercią z czasów drugiej wojny światowej.

Miejsce pamięci Jasenovac obejmuje tereny na pograniczu Bośni i Chorwacji. To tam za czasów NDH, w latach 1941-1945, funkcjonował obóz koncentracyjny (siedziba główna wraz z mniejszymi filiami). Wobec groźby zbliżających się wojsk partyzanckich w 1945 roku kompleks ten pospiesznie zlikwidowano. Do lat sześćdziesiątych miejsce to nie było zagospodarowane, pomijano je również w oficjalnej polityce pamięci. $W$ latach sześćdziesiątych się to zmieniło, wtedy na tym terenie powstał m.in. pomnik upamiętniający ofiary (kamienny kwiat zaprojektowany przez wybitnego serbskiego architekta, Bogdana Bogdanovicia), a następnie w nowo otwartym muzeum po raz pierwszy udostępniono zwiedzającym wystawę.

Do końca lat osiemdziesiątych pieczę nad polityką historyczną w Jugosławii sprawowała partia komunistyczna, dlatego też wszelkie obrzędy upamiętniania podporządkowane były idei walki z faszystowskim najeźdźcą. Miały one charakter wspólnotowy, a zarówno ofiary, jak i winni zbrodni pozbawieni byli narodowego oznacznika, symbolizowali zmitologizowaną opozycję, na której przez lata opierało się istnienie jugosłowiańskiego państwa: partyzanci - faszyści. Państwo jugosłowiańskie, niwelując potencjalne spory na polu narodowym (zwłaszcza serbsko-chorwackie), konsekwentnie prowadziło działania mające na celu umacnianie wspólnej tożsamości, jednocześnie na dalszy plan spychając fakt, iż kompleks obozowy Jasenovac powstał po to, by oczyścić NDH z przedstawicieli niepożądanych nacji (a więc przede wszystkim z Serbów, Żydów i Romów) oraz przeciwników ideologicznych (w obozie znajdowali się również chorwaccy więźniowie polityczni) ${ }^{20}$.

W latach 1999-2004 w muzeum zorganizowano trzy wystawy. W 2006 roku, bezpośrednio po jego renowacji, otwarto ekspozycję stałą, która wzbudziła wiele kontrowersji i dyskusji. Danilo Trbojević, cytując krytyczne opinie dotyczące wystawy, podkreśla, że najważniejszy zarzut dotyczył manipulacji prawdą historyczną za pośrednictwem ekspozycji. W tym kontekście serbski autor cytuje byłego prezydenta Chorwacji, Stipe Mesicia, który w 2010 roku podczas upamiętnienia ofiar

20 O historii tego miejsca i przekazie ideologicznym w wypowiedziach przedstawicieli chorwackich władz państwowych piszą Falski i Rawski (zob. Falski, Rawski). W artykule ich autorstwa znajdują się również wyczerpujące informacje na temat Bleiburga, o którym będzie mowa w dalszej części niniejszego tekstu. 
obozu wyraził opinię, że nadszedł czas, aby uzupełnić wystawę w taki sposób, by umożliwić młodzieży pełny wgląd we wszystko, co miało miejsce w obozie. Powołanie się na prezydenta Chorwacji ma na celu - jak się wydaje - podkreślenie, iż strona chorwacka również nie jest zadowolona z przekazu, jaki płynie z ekspozycji. Trbojević wielokrotnie przywołuje również opinię Juliji Koš, byłej członkini zarządu miejsca pamięci Jasenovac - jak sam przyznaje osoby uznawanej w Chorwacji za kontrowersyjną - która krytykowała wszystkie części wystawy jeszcze zanim została ona udostępniona zwiedzającym. Koš twierdziła wręcz, że autor ekspozycji wyraźnie utożsamił się ze zbrodniarzami, a nie z ofiarami, zaś sama wystawa w znacznej mierze relatywizuje prawdę historyczną (Trbojević 73-75) ${ }^{21}$. Jak trafnie zauważają polscy autorzy, debata, która toczyła się wokół nowej ekspozycji, szybko przerodziła się $\mathrm{w}$ dyskusję o przeszłości, a właściwie o interpretacji drugiej wojny światowej i chorwackiej tożsamości (Falski, Rawski).

Można pokusić się o stwierdzenie, że ofiarami z czasów drugiej wojny światowej manipuluje się w obu krajach. Kontrowersje związane z obozem w Jasenova$\mathrm{cu} w$ pewnym sensie odpowiadają polemikom, pojawiającym się w obu społeczeństwach w związku z upamiętnieniem Bleiburga. Nietrudno odnieść wrażenie, że oba miejsca pamięci sytuowane są wobec siebie symetrycznie, niejednokrotnie są wykorzystywane przez będących u władzy polityków w celach pragmatycznych. Upamiętnianie tragedii, jakie się $w$ nich wydarzyły, zawsze niesie ze sobą pewne naddane znaczenia, nigdy nie pozostaje ideologicznie neutralne. Analizując spory związane z dramatycznymi wydarzeniami z niedawnej historii, które toczą się w samej Chorwacji, Pavlaković stawia tezę, że społeczeństwo chorwackie po okresie wojny ojczyźnianej (1991-1995), kiedy niezwykle mocno się zintegrowało, w kolejnych latach gwałtownie się podzieliło. Polaryzacja społeczeństwa najwyraźniej uwidacznia się właśnie podczas tego typu obchodów, a zatem spór motywowany jest wydarzeniami z drugiej wojny światowej, które wciąż są żywe w społeczeństwie.

21 Jak wynika z fragmentu tekstu Trbojevicia, spór koncentruje się wokół liczby ofiar, braku wyraźnego wyodrębnienia nacji, które poniosły największe straty (np. zastąpienia klucza liczebnego spisem alfabetycznym narodów, których przedstawiciele zginęli w Jasenovacu) oraz przynależności narodowej winnych zbrodni. Obok tego pojawiają się również uwagi krytyczne, oparte na dość absurdalnych przesłankach, jak chociażby ta, że sposób prezentacji nazwisk zamordowanych (nazwiska te były wyświetlane na suficie) upodabnia muzeum do lotniska, a zaznajomienie się z nimi przez zwiedzającego jest niemożliwe, bowiem ich wyświetlanie trwa 11 godzin, gdy tymczasem muzeum można zwiedzać od 8 do 14. Te uwagi pochodzą z książki Salamona Jazbeca (Jazbec 2008). Należy podkreślić, że czytając książkę Trbojevicia, można odnieść wrażenie, iż najnowsze prezentacje znajdujące się w Jasenovacu przeczą prawdzie historycznej czy wręcz ją kwestionują. Zdaję sobie sprawę, że utopijne jest oczekiwanie, aby książka (tekst) była całkowicie neutralna światopoglądowo. Warto jednak zaznaczyć, że monografia Trbojevicia zdaje się mieć nieco zakamuflowaną, antychorwacką wymowę. Bardziej wyważony (bardziej obiektywny, jak się wydaje) sąd prezentuje Pavlaković, w artykule którego czytamy m.in.: "Choć niektórzy krytykowali muzeum, to jednak większość komentatorów w Chorwacji zgodziła się, że zaprezentowana w nim ekspozycja szanuje wszystkie ofiary, nie wykorzystując ich dla celów doraźnej polityki, jak to zdarzało się wcześniej" (Pavlaković 73). 
Drugim ważnym i wywołującym bardzo silne napięcia wśród Chorwatów punktem na mapie jest miejsce innej tragedii oraz traumy z drugiej wojny światowej, miejscowość Bleiburg. Leży ona w Austrii, blisko granicy ze Słowenią. To tam w maju 1945 roku partyzanci dokonali masakry Chorwatów oskarżanych o kolaborację $\mathrm{z}$ faszystami. Wbrew temu, co głoszą przedstawiciele partii prawicowych w Chorwacji, oprócz Chorwatów wśród zamordowanych znaleźli się również bośniaccy muzułmanie (wchodzący w skład wojska NDH), słoweńscy białogwardziści, serbscy i czarnogórscy czetnicy oraz spora liczba cywili ${ }^{22}$. Podobnie jak $\mathrm{w}$ przypadku zamordowanych w Jasenovacu, i tutaj spór pomiędzy Serbami i Chorwatami wiąże się z określeniem liczby ofiar. Jeszcze raz należy podkreślić, że niejednokrotnie dochodzi do przeciwstawiania sobie tych miejsc (wręcz swoistej licytacji zbrodniami) i związanych z nimi tragedii. Jest to obecne zarówno w sporze serbsko-chorwackim, jak i w samym społeczeństwie chorwackim, w którym oba miejsca (Jasenovac i Bleiburg) stają się symbolami alternatywnych wspólnot pamięci (Pavlaković; Falski, Rawski). Oficjalna pamięć socjalistycznego państwa jugosłowiańskiego z oczywistych względów nie obejmowała Bleiburga, przypominanie wydarzeń z wiosny 1945 roku podważyłoby bowiem wyraźnie moralną czystość partyzantów, a ponadto stałoby się potencjalnym zagrożeniem dla zadekretowanej jedności. Pamięć o masakrze mogłaby być również asumptem do chorwackich dążeń narodowych ${ }^{23}$. Pamięć o Bleiburgu przetrwała jednak w narracji emigrantów, którzy wyjechali z kraju tuż po wojnie, zaś w samej Chorwacji pierwsze oficjalne obchody upamiętnieniające ofiary odbyły się dopiero w latach dziewięćdziesiątych, choć ze względu na swą partyzancką przeszłość nigdy nie brał w nich udziału pierwszy prezydent Chorwacji, Franjo Tuđman. Po drugiej wojnie światowej hołd zamordowanym oddawano w tajemnicy (po raz pierwszy w 1952 roku, kiedy to trzech mężczyzn, którzy przeżyli masakrę, złożyło wieńce na cmentarzu, a kilkoro innych położyło tam broń).

Podobnie jak w przypadku Jasenovaca, i tu źródeł sporu pomiędzy Serbami a Chorwatami należy szukać $\mathrm{w}$ nieprecyzyjnej liczbie ofiar oraz w próbach jednoznacznego wskazania winnych za masakrę. Właśnie ten drugi aspekt ma znaczenie dla podziałów istniejących w samej Chorwacji. Osoby odpowiedzialne za tę tragedię można utożsamić z przedstawicielami narodu (Serbowie - stanowiący większość w szeregach partyzantów) bądź też z członkami/zwolennikami pewnej formacji (partyzanci - bez określania ich przynależności etnicznej). Zupełnie inną rolę ma w tym kontekście wykorzystanie przynależności narodowej bądź orientacji

22 Według historyków znaczna część ludzi zmarła nie w samym Bleiburgu, ale podczas tzw. marszów śmierci, które prowadziły przez Słowenię, Chorwację oraz inne byłe republiki Jugosławii (Borowiec).

23 Biorąc pod uwagę manipulację faktami oraz cichą zgodę na wykorzystanie retoryki i symboliki z czasów NDH podczas obchodów upamiętniania tragedii, można by powiedzieć, parafrazując słowa Domańskiej użyte w zupełnie innym kontekście, że w pewnych okolicznościach to, co pominięte, przemilczane, stłumione i zatarte, zyskuje swój głos i staje się opresywne (Domańska 19). 
ideologicznej. W przypadku winnych zbrodni w Jasenovacu uznanie, że Jasenovac był konsekwencją polityki ustaszy, nie stygmatyzuje całego chorwackiego narodu, zaś stwierdzenie, że za śmierć w obozie odpowiedzialni są Chorwaci, obarcza winą wszystkich jego członków. Analogicznie sprawa wygląda z Bleiburgiem. Inne reakcje wywołuje stwierdzenie, że to komuniści ponoszą odpowiedzialność, inne zaś uznanie Serbów za winnych. Na marginesie należy dodać, że szukanie winnych w obu narodach umacnia niesłuszne przekonanie, jakoby w oddziałach wojska NDH znajdowali się tylko Chorwaci, a ruch partyzancki obejmował jedynie Serbów ${ }^{24}$.

Ostatnia część niniejszego tekstu poświęcona zostanie pamięci o żydowskich ofiarach z czasów drugiej wojny światowej zamordowanych w Belgradzie. Miejsce, w którym ucierpieli przedstawiciele narodu żydowskiego, nie powinno - jak mogłoby się wydawać - podlegać próbom manipulacji dokonywanym przez przedstawicieli władzy. Jak się jednak okazuje, również narracja dotycząca Holokaustu nie jest w Serbii wolna od prób zawłaszczenia pamięci i instrumentalnego jej wykorzystania ${ }^{25}$. W Belgradzie, a nawet $\mathrm{w}$ całej Serbii, to tereny międzywojennych pawilonów wystawienniczych, tj. Staro sajmište są jednoznacznie kojarzone z Holokaustem ${ }^{26}$. Co ciekawe, dziś jest to teren, który za Jackiem Leociakiem określić można mianem nie-miejsca (Leociak) bądź obszarem zapomnienia. Jest to bowiem pusta przestrzeń, oddziałująca poprzez to, czego w niej fizycznie nie ma. Prześledzenie jej historii doskonale pokazuje, jak w ciągu ostatnich 60 lat zmieniała się oficjalna polityka pamięci (najpierw socjalistycznej Jugosławii, a później Serbiii²).

Sajmište obejmuje ziemię znajdującą się nad samym brzegiem Savy, naprzeciwko historycznego centrum stolicy, ale po drugiej stronie rzeki, tj. na jej zemuńskim brzegu. Już samo położenie sprawia, że jest to miejsce symboliczne ${ }^{28}$. Tuż przed drugą

$24 \mathrm{O}$ tym, że jest to błędne utożsamienie, pisze Pavlaković, który w swym tekście koncentruje się na konflikcie pomiędzy spadkobiercami „czarnej” / brunatnej i „czerwonej” Chorwacji. Na tej opozycji zbudowany został sam tytuł artykułu: „czerwone gwiazdy” są emblematami komunistów, zaś "czarne koszule" konotują zwolenników faszystowskiego państwa NDH (Pavlaković).

25 Jest tak zapewne również dlatego, że w obozie Sajmište ginęli nie tylko Żydzi, ale i serbscy antyfaszyści.

26 Wyczerpujące informacje o obozie można znaleźć na internetowej stronie dokumentującej badania nad serbską pamięcią o owym miejscu. Zob. Semlin Jugendlager, źródło elektroniczne.

27 Więcej na ten temat zob. Manojlović Pintar, Ignjatović.

28 Zemun, będący dziś jedną z dzielnic Belgradu, w przeszłości był odrębnym miasteczkiem. Ponadto niegdyś to tam właśnie przebiegała granica pomiędzy Serbią turecką (Belgrad leżał w jej obrębie) a Serbią austrowęgierską (Zemun był już miastem austriackim). Ślady owej przynależności zachowały się w architekturze tej części serbskiej stolicy. O podzielonym Belgradzie i miejscu niegdysiejszego obozu, słowami swej bohaterki Albahari mówi w ten sposób: „[...] nie osiedliśmy w Belgradzie tylko w Zemunie. [...] Dotarło do mnie, że to dwie części jednej całości, że tylko na pozór są rozdzielne i że kiedyś muszą się połączyć. Nigdy jednak nie potrafiłam, a nawet nie chciałam zapomnieć, że łączy je Sajmište, które z wolna, widać to było doskonale z trolejbusu czy autobusu, stawało się centrum tego nowego, wielkiego miasta. Nie myślałam oczywiście o tych, którzy kiedyś znajdowali się w tym miejscu, w obozie, skąd zabierano ich na rozstrzelanie albo do komory gazowej, ich i tak nic nie mogło przywrócić do życia, ale nie potrafiłam zdusić w sobie 
wojną światową (w 1937 roku) tereny zostały przeznaczone na centrum wystawienniczo-targowe. Pierwotnie przestrzeń ta miała zatem pełnić funkcję komercyjną. Usytuowanie w tym miejscu tego typu centrum wskazywało na przyszłe plany urbanizacyjne Belgradu, który w zamierzeniu władz miasta miał się rozrastać i wchłaniać tereny podmiejskie. Trbojević zauważa, że Sajmište odegrało również ważną rolę w promocji państwa na zewnątrz (prezentowano tam przykłady technologicznego, ekonomicznego i gospodarczego rozwoju Jugosławii). Dla samych Jugosłowian zaś tereny targowe, za sprawą swego usytuowania, pełniły rolę integracyjną, łączyły bowiem ze sobą dwie Serbie (dawną Serbię turecką i austriacką) (Trbojević 83).

Inną rolę wyznaczyli Sajmištu Niemcy, którzy w 1941 r. utworzyli tam obóz (niem. Semlin) ${ }^{29}$. Do połowy 1942 roku pełnił on funkcję obozu koncentracyjnego, w którym umieszczano przede wszystkim żydowskie kobiety, dzieci i osoby w podeszłym wieku (Judenlager Semlin). Po likwidacji około 7000 serbskich Żydów obóz zmienił przeznaczenie i stał się obozem przejściowym, przeznaczonym dla sympatyków i członków organizacji antyfaszystowskich z całej Jugosławii (Anhaltelager Semlin). W wyniku bombardowań stolicy, jakie miały miejsce w 1944 roku, znaczna część budynków wchodzących w skład kompleksu została zniszczona. Lata powojenne to okres, w którym tereny byłego obozu były pozostawione same sobie, a materialne artefakty przeszłości podlegały naturalnej erozji i zawłaszczeniu przez otaczającą je przyrodę. Sceneria, w której dokonywano mordów ludności żydowskiej, nie była miejscem znaczącym aż do połowy lat siedemdziesiątych, kiedy to ustawiono tam tablicę poświęconą pamięci ofiar ${ }^{30}$. Należy podkreślić, że wcześniej na terenie, na którym usytuowany był kompleks obozowy, spontanicznie powstawały miejsca rekreacji służące mieszkańcom stolicy do aktywnego spędzania wolnego czasu, wyznaczano tam kąpieliska (tzw. belgradzka Kopakabana), tworzono również dzikie osiedla.

Interesujące wydają się przyczyny, dla których to miejsce zagłady nie otrzymało dotąd należnego mu statusu. Srđan Radović za taki stan rzeczy wini specyfikę lat powojennych. Wówczas koncentrowano się przede wszystkim na budowaniu nowego socjalistycznego społeczeństwa, które - jak już wcześniej tutaj zauważo-

podejrzenia, że to nowe miasto, rezygnując z zauważenia ich nieobecności, w istocie ich poniża" (Albahari 2008: 96).

29 Właśnie w tej funkcji Sajmište pojawia się w twórczości Albahariego. Jest miejscem śmierci i punktem, z którego wywożono Żydów na miejsce straceń Jajinci, początkowym przystankiem w drodze ciężarówki śmierci, w której duszono jej pasażerów (Albahari 2007; 2008). Obozy zakładano również w takich miejscach jak Topovskie šupy, Banjica i Šabac. Losowi Żydów z Šabca poświęca swoją uwagę Chorwatka, Daša Drndić w książce Belladonna (Drndić). Historię obozu Sajmište przedstawiają książki m.in. Milana Koljanina Nemački logor na Beogradskom Sajmištu 1941-1944 (Koljanin) czy Jovana Bajforda, Staro sajmište. Mesto sećanja, zaborava $i$ sporenja (Bajford).

30 Wcześniej, w 1965 roku, na lewym brzegu Savy wyznaczony został pas ziemi o długości $302 \mathrm{~m}$, któremu nadano nazwę brzegu pamięci (spomen-obala). W 1974 i 1984 roku umieszczono tam tablice upamiętniające (spomen ploče). 
no - ufundowane było na idei walki ze wspólnym, pokonanym (faszystowskim) wrogiem. A zatem potencjalne przywoływanie w aktach upamiętniających konfesyjnej i etnicznej przynależności zamordowanych na terenie obozu Sajmište kłóciło się z ówczesnym rozumieniem ofiar. Do tych oficjalnie należeli wyłącznie ci, którzy odpierali faszyzm i walczyli o socjalistyczną przyszłość. Radović zauważa też, że za "dyżurne" miejsca cierpień zwolenników komunizmu w powojennej Jugosławii przyjęło się uznawać obóz Banjica ${ }^{31}$, do którego kierowano więźniów politycznych, i wchodzące w jego obręb miejsce masowych mordów Jajinci, co automatycznie usuwało w cień Sajmište, kojarzone przede wszystkim z ofiarami cywilnymi, przedstawicielami narodu żydowskiego. Do bardziej pragmatycznych powodów braku zainteresowania upamiętnieniem kompleksu nad Savą należy fakt, że część terenów, na których się znajdował, po wojnie trafiła do rąk prywatnych właścicieli (Radović 2008; 2013). Przyczyny niepamięci o obozie Sajmište doskonale pokazują, jak wybór miejsc pamięci ważnych dla wspólnoty reprodukuje moc i utrwala idee promowane przez rządzących. Upraszczając, można by powiedzieć, że jugosłowiańska homogenizacja narodu zakładała, że mniejsze znaczenie ma bycie Żydem niż bycie komunistą (antyfaszystą). A zatem to ze specyfiki percepcji Holokaustu w socjalizmie wynikają zaniedbania $\mathrm{w}$ pamięci o tym miejscu.

Od drugiej połowy lat osiemdziesiątych na terenie byłego obozu 9 maja, w Dniu Zwycięstwa (nad faszyzmem), odbywają się oficjalne uroczystości upamiętniające ofiary. Ten wzrost zainteresowania samym obozem i komemoracjami na jego terenie badacze uznają za efekt sytuacji socjopolitycznej. Tłumaczą je nasilającym się $\mathrm{w}$ latach osiemdziesiątych w Serbii nacjonalizmem i rozbuchaną narodową martyrologią, w wyniku której Serbowie zaczynają identyfikować się z narodami, które $\mathrm{w}$ historii były ofiarami. Następstwem takiego sposobu myślenia jest drobna (ale jakże znacząca) zmiana w sposobie określania ofiar zamordowanych w obozie, jakiej dokonano w połowie lat dziewięćdziesiątych: od tego czasu w kontekście wydarzeń z obozu Sajmište mówi się o "serbskich ofiarach faszyzmu” (wcześniej nie wskazywano ich przynależności etnicznej, mówiono po prostu o "ofiarach faszyzmu") $(\text { Trbojević } 87)^{32}$. Lata transformacji i powolnej demokratyzacji Serbii nie spowodo-

31 Strony poświęcone obozowi w Banicy to: Web. 28.11.2015 <http://beogradskonasledje.rs/kd/ zavod/vozdovac/banjicki_logor.html>, <http://www.republika.co.rs/460-461/32.html>.

32 Mechanizmy zawłaszczania miejsc pamięci w obu krajach (tj. w Serbii i Chorwacji) są analogiczne. Dobitnie świadczy o tym incydent przywoływany przez Falskiego i Rawskiego. Otóż w latach 2006-2008 w Chorwacji toczył się spór o napis na pomniku w Bleiburgu. Podczas jego renowacji pierwotny tekst, w którym znalazło się określenie "chorwackie wojsko", zastąpiono wyrażeniem "niewinne ofiary". Ta - wydawałoby się - drobna korekta rodzi nieco inną wymowę (za sprawą dokonanej zmiany w określeniu podmiotu tragedii). W wyniku sprzeciwów i polemik powrócono do pierwotnego napisu (Falski, Rawski). Co ciekawe, w czasie wojny w Bośni i Hercegowinie (dokładnie w 1995 roku) niegdysiejsza lokacja obozu na belgradzkim brzegu Savy przejmuje funkcję Jasenovaca. Trbojević pisze w tym kontekście o „rezerwowym Jasenovacu". Ma to związek z faktem, iż w czasie akcji Burza siły chorwackie przejęły kontrolę nad terenem, na którym znajdował się kompleks Jasenovac. W związku z tym serbskie elity 
wały wzrostu zainteresowania belgradzkim miejscem pamięci, wprost przeciwnie. Tereny wokół byłego obozu są przeznaczane pod wynajem dla przedsiębiorców, tworzących tam miejsca rekreacji i rozrywki dla mieszkańców Belgradu ${ }^{33}$.

W kontekście tego, co zostało już tutaj powiedziane, przypomnijmy, że Holokaust jest tym wydarzeniem, które wpisuje się w globalną pamięć, jednocześnie w jakimś sensie odsuwając czy wręcz spychając w niepamięć te wydarzenia $\mathrm{z}$ historii narodowej, które mogłyby zająć ważkie miejsce wśród fundamentów lokalnej tożsamości. Z tego właśnie względu w Serbii bywały okresy, w których Sajmište nie przykuwało uwagi polityków, a co za tym idzie było pomijane w dyskursie martyrologicznym. Kuljić nazywa praktyki komemoratywne związane z Shoah wyrazem nowej kosmopolitycznej pamięci i zauważa, że u jej podstaw stoi pierwotna dekontekstualizacja, która - za sprawą przyswojenia sobie tego wydarzenia przez popularną kulturę - ulega następnie uniwersalizacji ${ }^{34}$. Serbski badacz przywołuje $w$ tym kontekście film Stevena Spielberga Lista Schindlera, za sprawą którego Holokaust stał się symbolem odwiecznej walki dobra ze złem (Kuljić 2006: 216-217) ${ }^{35}$. Wydaje się jednak, że Kuljić pomija pewien fakt. Owej „kosmopolityzacji pamięci” o ofiarach Zagłady może bowiem towarzyszyć swoista jej regionalizacja (plan glokalny). To z kolei stwarza nadzieję na zerwanie $\mathrm{z}$ instrumentalnym wykorzystywaniem przeszłości.

$\mathrm{O}$ pewnych przekształceniach $\mathrm{w}$ traktowaniu tragicznych wydarzeń $\mathrm{z}$ przeszłości świadczą niedawne zmiany w sposobie upamiętniania ofiar obozu Sajmište. Serbia przez wiele lat nie upamiętniała Shoah w dniu, który powszechnie został uznany niemal na całym świecie za Dzień Pamięci o Ofiarach Holokaustu (27 stycznia - tj. w rocznicę wyzwolenia Auschwitz). W Serbii dzień ten obchodzono 22 kwietnia, a więc $\mathrm{w}$ rocznicę próby ucieczki grupy więźniów z obozu w Jasenovacu. W tym przesunięciu dochodzi do wyparcia pamięci o Holokauście i przesłonięcia jej w pewnym stopniu zmanipulowaną pamięcią o ofiarach własnego narodu (zapomina się przy tym, że Żydzi zamordowani chociażby w obozie

utraciły możliwość przybycia na miejsce upamiętniania. Wówczas symboliczne znaczenia tego obozu przejęło Sajmište (Trbojević 88).

33 Kuriozalny jest fakt, że w jednym z zachowanych obiektów kompleksu obozowego, Spasićev paviljon, pełniącym w czasie wojny funkcję szpitalu obozowego, powstał klub muzyczny Posejdon. To za jego sprawą obóz zaistniał w świadomości mieszkańców Belgradu na początku XXI wieku. Mianowicie w 2007 roku, wskutek interwencji serbskich i międzynarodowych organizacji żydowskich, doszło do odwołania koncertu grupy rockowej, która miała tam wystąpić. Radović, przywołując oświadczenia właścicieli lokalu, wspomina również o tym, że już po odwołaniu koncertu zapowiedziano w Posejdonie mecz bokserski (miał się on odbyć w grudniu 2007 roku) (Radović).

34 Uzupełnieniem tej uwagi są wątpliwości, które pojawiły się podczas dyskusji nad miejscem sztuki w muzeach martyrologicznych. Zapis dyskusji stanowi integralną część książki Obóz-muzeum. Pada tam pytanie o to, co mają wynieść z odwiedzin w takim muzeum młodzi ludzie, oraz jak sprawić, by wystawa osiągnęła zamierzony efekt, jeśli zdarza się, że ekspozycja muzealna w konfrontacji z materiałami z Internetu i obrazami wykreowanymi przez media wypada blado i rozczarowuje (Obóz-muzeum 131).

35 Amerykański film jest często przywoływany jako przykład pierwszej tak wyraźnej i doskonale przyjętej przez publiczność komercjalizacji Holokaustu (Hirsch 253-284; Hansen 173-201). 
Sajmište również byli Serbami). W 2008 roku Serbia obchodziła Dzień Pamięci wraz z całym światem, co można odczytywać jako znak wyższości wartości uniwersalnych nad lokalnymi/narodowymi dla władz kraju ${ }^{36}$. Na prawdopodobny cel tego typu działań zwraca uwagę Tomasz Majewski, zauważając, że od lat dziewięćdziesiątych możemy obserwować instrumentalizację pamięci o Shoah. Zabiegi te wiąże z polityką władz oraz instytucji, „w której problem zagłady, pojednania czy przebaczenia «przewin historycznych» coraz wyraźniej wpisuje się w porządek osiągania celów związanych z międzynarodowym statusem" (Majewski 256). Trudno jednoznacznie orzec, czy powolne, choć zauważalne odejście od nacjonalizmu w praktykach komemoratywnych i stopniowy renesans pamięci o żydowskich ofiarach drugiej wojny światowej ma u swych podstaw autentyczną refleksję, czy też wynika z cynicznej kalkulacji związanej z aspiracjami Serbii do członkostwa w Unii Europejskiej.

Na przykładzie narracji o Jasenovacu oraz Bleiburgu starałam się pokazać, w jaki sposób na terenie Serbii i Chorwacji różne pamięci konkurują ze sobą i ścierają się $\mathrm{w}$ walce o przestrzeń, głos i miejsce w historii ${ }^{37}$. Miejsce zagłady Żydów, Staro sajmište - opisane $\mathrm{w}$ niniejszym tekście jako trzecie - mogłoby stać się wzorcowym przykładem przestrzeni, która nie dzieli, nie polaryzuje postaw i sądów, ale uniwersalizując traumatyczne doświadczenie, staje się punktem wspólnej opowieści. Dobrosąsiedzkie stosunki z krajami znajdującymi się tuż obok, przyszłość w ramach organizacji międzynarodowych i budowanie wspólnego, zgodnego społeczeństwa obywatelskiego wymagają uleczenia pamięci, podjęcia prób obiektywnego spojrzenia na własną przeszłość i gotowości zmiany własnego obrazu, na co - jak nam się wydaje - oba społeczeństwa nie są jednak wciąż gotowe.

\section{BIBLIOGRAFIA}

Albahari, David. Götz i Meyer. Przeł. Milan Duškov. Toruń: Graffiti BC, 2007.

Albahari, David. Mamidło. Przeł. Dorota J. Ćirlić. Warszawa: WAB, 2008.

Borowiec, Aleksandra. „Termin «droga krzyżowa» w najnowszej historii Chorwacji”. Przemiany w świadomości i kulturze duchowej narodów Jugosławii po 1991 roku. Red. J. Kornhauser. Kraków: Wydawnictwo Uniwersytetu Jagiellońskiego, 1999. S. 79-85.

Bajford, Jovan. Staro sajmište. Mesto sećanja, zaborava i sporenja, Beograd: Beogradski centar za ljudska prava, 2011.

36 Trbojević wskazuje ponadto, że w ciągu ostatnich 60 lat, w zależności od obowiązującej w kraju polityki pamięci, zmieniała się funkcja, jaką w niej pełnił teren po obozie na brzegu Savy. Co ciekawe, w 2008 roku, za czasów prezydentury Borislava Tadicia, obchody upamiętnienia ofiar Holokaustu odbywały się gdzie indziej. Tę decyzję Trbojević odczytuje jako próbę odcięcia się przez prezydenta od tych przedstawicieli władz Serbii, którzy niegdyś wykorzystywali to miejsce pamięci w celach promocji nacjonalistycznych wartości i poglądów (Trbojević 90-93).

37 Nawiązuję tutaj do refleksji Idith Zertal na temat konkurujących ze sobą izraelskich narracji o Zagładzie (Zertal). 
Bosto Sulejman, Cipek Tihomir, Milosavljević Olivera, red. Kultura sjećanja. Povijesni lomovi i svladavanje prošlosti: 1941. Zagreb: Disput, 2008. Web. 21.12.2015. <http://library.fes.de/pdf-files/bueros/ sarajevo/06043.pdf>

Cipek Tihomir, Milosavljević Olivera, red. Kultura sjećanja. Povijesni lomovi i svladavanje prošlosti: 1918. Zagreb: Disput, 2007.

Cipek Tihomir, red. Kultura sjećanja. Povijesni lomovi i svladavanje prošlosti: 1991. Zagreb: Disput, 2011.

Connerton, Paul. Jak społeczeństwa pamiętają. Przeł. Marcin Napiórkowski. Warszawa: Wydawnictwo Uniwersytetu Warszawskiego, 2012.

Dąbrowska-Partyka, Maria. Literatura pogranicza, pogranicza literatury. Kraków: Wydawnictwo Uniwersytetu Jagielońskiego, 2004.

Domańska, Ewa. „O poznawczym uprzywilejowaniu ofiary (Uwagi metodologiczne)”. (Nie)obecność. Pominięcia i przemilczenia w narracjach XX wieku. Red. H. Gosk, B. Karwowska. Warszawa: Dom Wydawniczy Elipsa, 2008. S. 19-36.

Drndić, Daša. Belladonna. Zaprešić: Fraktura, 2012.

Dyras, Magdalena. Re-inkarnacje narodu. Chorwackie narracje tożsamościowe w latach dziewięćdziesiątych XX wieku. Kraków: Wydawnictwo Uniwersytetu Jagiellońskiego, 2009.

Đerić Gordana, red. Intima javnosti. Okviri predstavljanja, narativni obrasci, strategie i stereotipi konstruisanja Drugosti u upečatliivim događajima tokom razgradnje Jugoslavije: štampa, TV, film. Beograd: Fabrika knjiga, 2008.

Đerić Gordana, red. Pamćenje i nostalgija. Neki prostori, oblici, lica i naličja. Beograd: Filip Višnjić, 2009.

Falski, Maciej. „Oficjalne ramy polityki pamięci w Chorwacji”. Pamiętnik Stowiański LX, Z. 2 (2010). S. 35-49.

Falski Maciej, Rawski Tomasz. „Jasenovac, Bleiburg, Vukovar: miejsca pamięci a dyskurs publiczny”. Obóz-Muzeum. Trauma we wspótczesnym wystawiennictwie. Red. M. Fabiszak, M. Owsiński. Kraków: Universitas, 2013. S. 193-214.

Freud, Zygmunt. „Przypomnanie, powtarzanie, przepracowanie”. Przeł. Anna Czownicka. Pospiszyl, Kazimierz Zygmunt Freud. Człowiek i dzieło. Wrocław: Zakład Narodowy im. Ossolińskich, 1991a. S. 295-308.

Freud, Zygmunt. „Żałoba i melancholia”. Przeł. Barbara Kocowska. Pospiszyl, Kazimierz Zygmunt Freud. Człowiek i dzieło. Wrocław: Zakład Narodowy im. Ossolińskich, 1991b. S. 266-272.

Gil, Dorota. Prawostawie. Historia. Naród. Miejsce kultury duchowej w serbskiej tradycji i wspótczesności. Kraków: Wydawnictwo Uniwersytetu Jagiellońskiego, 2005.

Hansen, Miriam Bratu. „«Lista Schindlera» to nie «Shoah»: drugie przykazanie, modernizm popularny i pamięć publiczna”. Przeł. Tamara Skalska, przejrzeli i poprawili Tomasz Majewski, Agnieszka Rejniak-Majewska. Teoria - literatura - życie. Praktykowanie teorii w humanistyce wspótczesnej. Red. A. Legeżyńska, R. Nycz. Warszawa: Wydawnictwo IBL, 2012. S. 173-201.

Hirsch, Joshua. „Postmodernizm, drugie pokolenie i międzykulturowe kino postraumatyczne”. Przeł. Tomasz Bilczewski, Anna Kowalcze-Pawlik. Antologia studiów nad trauma. Red. A. Łysak. Kraków: Universitas, 2015. S. 253-284.

Jawoszek, Agata. Boszniacy. Literackie narracje tożsamościowe po 1992 roku. Poznań: Wydawnictwo Nauka i Innowacje, 2014. 
Jazbec, Salamon. Magnissimum crimen. Pola vijeka revizionizma u Hrvata. Zagreb: Margelov institut, 2008. Koljanin, Milan. Nemački logor na Beogradskom Sajmištu 1941-1944. Beograd: Institut za savremenu istoriju, 1992.

Kuljić, Todor. Kultura sećanja. Teorijska objašnjenja upotrebe prošlosti. Beograd: Čigoja štampa, 2006.

Kuljić, Todor. Prevladanje prošlosti. Uzroci i pravci promene slike istorije krajem XX veka. Beograd: Helšinski odbor za ljudska prava u Srbiji, 2002.

LaCapra, Dominick. Historia w okresie przejściowym. Doświadczenie, tożsamość, teoria krytyczna. Przeł. Katarzyna Bojarska. Kraków: Universitas. 2009.

LaCapra, Dominick. „Trauma, nieobecność, utrata”. Przeł. Katarzyna Bojarska. Antologia studiów nad trauma. Red. T. Łysak. Kraków: Universitas, 2015. S. 59-107.

Leociak, Jacek. Doświadczenia graniczne. Studia o dwudziestowiecznych formach reprezentacji. Warszawa: Wydawnictwo IBL, 2009.

Majewski, Tomasz. „Dyskurs publiczny po Shoah”. Pamięć Shoah. Kulturowe reprezentacje i praktyki upamiętniania. Red. T. Majewski, A. Zeidler-Janiszewska. Łódź: Wydawnictwo Officyna, 2011. S. 251-257.

Manojlović Pintar Olga, Ignjatović Aleksadar. „Prostori selektivnih memorija: Staro sajmište u Beogradu i sećanje na drugi svetski rat". Kultura sjećanja. Povijesni lomovi i svladavanje prošlosti: 1941. Red. B. Sulejman, T. Cipek, O. Milosavljević. Zagreb: Disput, 2008. S. 95-112. Web. 21.12.2015. <http://library.fes.de/pdf-files/bueros/sarajevo/06043.pdf>

Martinov, Zlatoje. „Logor Banjica - važno mesto u istoriji zločina”. 2009. Web. 29.12.2015. <http://www.republika.co.rs/460-461/32.html>

Miodyński, Lech. Powrót znaczeń. Aktualizacje tradycji kulturowych w literaturze macedońskiej po 1945 roku. Katowice: Wydawnictwo Uniwersytetu Śląskiego, 1999.

Nora, Pierre. „Między pamięcią i historią: Les lieux de Mémoire”. 2009. Web. 14.12.2015.

<http://www.marysialewandowska.com/wp-content/uploads/2009/08/Archiwum-no2-c2-sprd.pdf.> Pavlaković, Vjeran. „Crvene zvezde, crne košulje: simboli, komemoracije i sukobljene istorije Drugog svetskog rata u Hrvatskoj". Przeł. Borivoj Gerzić. Pamćenje i nostalgija. Neki prostori, oblici, lica i naličja. Red. G. Đerić. Beograd: Filip Višnjić, 2009. S. 43-81.

Pekić, Borislav. Godine koje su pojeli skakavci, wyd. 2. Beograd: BIGZ-Jedinstvo, 1988.

Pekić, Borislav. Graditelji. Beograd: BIGZ, 1994.

Pekić, Borislav. Hodošće Arsenija Njegovana. 1970.

Pekić, Borislav. Pielgrzymka Arsenijego Njegovana. Przeł. Grzegorz Łatuszyński, Warszawa: PIW, 1985.

Perica Vjekoslav, Velikonja Mitija. Nebeska Jugoslavija. Interakcije političkih mitologija i pop-kulture. Beograd: Biblioteka XX vek, 2012.

Radović, Srđan. „Gradski prostori od mesta do nemesta, i vice versa: slučaj beogradskog Starog sajmišta". Spomen mesta: istorija, sećanje. Red. A. Pavićević. Beograd: Etnografski institut SANU, 2009. S. 142-160.

Radović, Srđan. "Memory Culture and Urban Reconstruction: The Case of Staro Sajmište in Belgrade". Transitional Justice. Images and Memories. Ed. by Ch. Brants, A. Hol, D. Siegel. London: Routledge, 2013. Web. 20.12.2015. 
<https:/ / books.google.pl/ books?id=QZpQoL0juvMC\&pg=PT138\&lpg=PT138\&dq=Radovi\%C4\%87+Srdjan,+Memory\&source=bl\&ots=M197B-NyQ4\&sig=ZKoIiefyjHbNECHPBzMm$\mathrm{m} \_\mathrm{x} \_$HOc\&hl=pl\&sa=X\&ved=0ahUKEwj5_PDS5JfKAhXmEXIKHdSaC8UQ6AEIPjAF\#v=onepage\&q=Radovi $\%$ C4\%87\%20Srdjan $\% 2 \mathrm{C} \% 20$ Memory\&f=false $>$

Rapacka, Joanna. Godzina Herdera. O Serbach, Chorwatach i idei jugostowiańskiej. Warszawa: Wydawnictwo Energeia, 1995.

Ricoeur, Paul. Pamięć, historia, zapomnienie. Przeł. Janusz Margański, Kraków: Universitas, 2007.

Rihtman-Auguštin, Dunja. Ulice moga grada. Antropologija domaćeg terena, Beograd: Biblioteka XX vek, 2000.

Sabor, Agnieszka. „Pamięć i polityka”. Herito 1 (2010). S. 147-149.

Selenić, Slobodan. Ci dwaj mężczyźni. Przeł. Magdalena Petryńska. Warszawa: PIW, 1988.

Selenić, Slobodan. Memoari Pere Bogalja. Beograd: Prosveta, 1968.

Selenić, Slobodan. Pamiętnik Piotra Kaleki. Przeł. Magdalena Petryńska. Warszawa: PIW, 1971.

Selenić, Slobodan. Prijateljisa Kosančićevog venca, wyd. 2. Beograd: BIGZ, 1986.

Szpociński, Andrzej. „Miejsca pamięci (lieux de memoire)”. 2008. Web. 14.12.2015. <http://rcin.org.pl/ ibl/Content/50928/WA248_67233_P-I-2524_szpocinski-miejsca.pdf>

Sztompka, Piotr. „Trauma kulturowa. Druga strona zmiany społecznej”. Los i wybór. Dziedzictwo i perspektywy społeczeństwa polskiego. Red. A. Kojder, K.Z. Sowa. Rzeszów: Wydawnictwo Uniwersytetu Rzeszowskiego, 2003.

Trbojević, Danilo. Sećanje na zlo. Politika komemoracije žrtava nacističkih ustaških logora. Beograd: Srpski genealoški centar, 2014.

Young, James. „Pamięć i kontrpamięć. W poszukiwaniu społecznej estetyki pomników Holokaustu”. Literatura na Świecie 1-2 (2004). S. 267-289.

Zertal, Idith. Naród i śmierć. Zagłada w dyskursie i polityce Izraela. Przeł. Jan Maria Kłoczowski. Kraków: Znak, 2010.

Semlin Jugendlager Web. 29.12.2015. < http://www.open.ac.uk/socialsciences/semlin/>

Web. 28.11.2015. <http:// beogradskonasledje.rs/kd/zavod/vozdovac/banjicki_logor.html> 